\title{
Temperature index melt modelling in mountain areas
}

\author{
Regine Hock* \\ Department of Physical Geography and Quaternary Geology, Stockholm University, SE-106 91 Stockholm, Sweden
}

\begin{abstract}
Temperature index or degree-day models rest upon a claimed relationship between snow or ice melt and air temperature usually expressed in the form of positive temperatures. Since air temperature generally is the most readily available data, such models have been the most widely used method of ice and snow melt computations for many purposes, such as hydrological modelling, ice dynamic modelling or climate sensitivity studies. Despite their simplicity, temperature-index models have proven to be powerful tools for melt modelling, often on a catchment scale outperforming energy balance models. However, two shortcomings are evident: (1) although working well over long time periods their accuracy decreases with increasing temporal resolution; (2) spatial variability cannot be modelled accurately as melt rates may vary substantially due to topographic effects such as shading, slope and aspect angles. These effects are particularly crucial in mountain areas. This paper provides an overview of temperature-index methods, including glacier environments, and discusses recent advances on distributed approaches attempting to account for topographic effects in complex terrain, while retaining scarcity of data input. In the light of an increasing demand for melt estimates with high spatial and temporal resolution, such approaches need further refinement and development.
\end{abstract}

(C) 2003 Elsevier B.V. All rights reserved.

Keywords: Temperature index models; Degree-day factor; Melt modelling; Glacier mass balance

\section{Introduction}

Melt modelling is a crucial element in any attempt to predict runoff from snow-covered or glacierised areas, as well as to assess changes in the cryosphere associated with climate change. In mountainous regions, snow and ice significantly affect catchment hydrology by temporarily storing and releasing water on various time scales (Jansson et al., 2003). This causes distinct annual and diurnal discharge variations significantly differing from those of conventional landscapes (Röthlisberger and Lang, 1987). Hence, success of runoff modelling in such areas largely depends on accurate quantification of the melt

\footnotetext{
* Tel.: +46-8-16-47-84; fax: +46-8-16-48-18.

E-mail address: regine.hock@natgeo.su.se (R. Hock).
}

process. Melt models generally fall into two categories: energy balance models, attempting to quantify melt as residual in the heat balance equation, and temperature-index models assuming an empirical relationship between air temperatures and melt rates. Such a relation was first used for an Alpine glacier by Finsterwalder and Schunk (1887) and has since then been widely applied and further refined (e.g. Clyde, 1931; Collins, 1934; Corps of Engineers, 1956; Hoinkes and Steinacker, 1975; Braithwaite, 1995). Temperature index models have been the most common approach for melt modelling due to four reasons: (1) wide availability of air temperature data, (2) relatively easy interpolation and forecasting possibilities of air temperature, (3) generally good model performance despite their simplicity and 
(4) computational simplicity. Applications cover a wide range including prediction of melt for operational flood forecasting and hydrological modelling (WMO, 1986). Most operational runoff models, e.g. HBV-model (Bergström, 1976), SRM-model (Martinec and Rango, 1986), UBC-model (Quick and Pipes, 1977), HYMET-model (Tangborn, 1984) and even versions of the physically based SHE-model (Bøggild et al., 1999) rely on temperature-index methods for melt modelling. Temperature index models also provide the mass balance forcing for most ice dynamic models (e.g. Oerlemans et al., 1998) and they have been used to predict the response of glacier mass balance to climate change (e.g. Bøggild et al., 1994; Braithwaite and Zhang, 1999). This paper provides a synthesis of the use of temperature-index methods for melt modelling including glacierised areas. It is concluded that temperature-index models need to be enhanced in order to bridge the gap between restricted data availability and increasing demand for high resolution estimates of melt rates in space and time.

\section{Physical basis of temperature-index models}

Many studies have revealed a high correlation between melt and air temperature. Braithwaite and Olesen (1989) found a correlation coefficient of 0.96 between annual ice ablation and positive air temperature sums. Although involving a simplification of complex processes that are more properly evaluated by the energy balance of the glacier surface, temperature-index models often match the performance of energy balance models on a catchment scale (WMO, 1986). The reason for the success of air temperature as the sole index of melt energy in spite of the predominance of net radiation as a source of melt energy is attributed to the high correlation of temperature with several energy balance components (Ambach, 1988b; Sato et al., 1984; Braithwaite and Olesen, 1990; Lang and Braun, 1990). Ohmura (2001) analyzed the physical basis of temperature-index models and stressed the role of longwave atmospheric radiation: Usually, the latter is by far the most important heat source for melt, and together with the sensible heat flux, provide about $3 / 4$ of the entire energy source for melt. Both heat fluxes are highly affected by air temperature, which provides the main reason for the close relationship between melt and air temperature. In addition, temperature is in part affected by global radiation (Kuhn, 1993; Ohmura, 2001), the secondary source of heat for melt.

\section{Degree-day factors}

\subsection{Definition and influencing factors}

Temperature index models or degree-day models are based on an assumed relationship between ablation and air temperature usually expressed in the form of positive temperature sums. The most basic formulation relates the amount of ice or snow melt, $M$ $(\mathrm{mm})$, during a period of $n$ time intervals, $\Delta t(\mathrm{~d})$, to the sum of positive air temperatures of each time interval, $T^{+}\left({ }^{\circ} \mathrm{C}\right)$, during the same period, the factor of proportionality being the degree-day factor, DDF, expressed in $\mathrm{mm} \mathrm{d}^{-1}{ }^{\circ} \mathrm{C}^{-1}$.

$\sum_{i=1}^{n} M=\mathrm{DDF} \sum_{i=1}^{n} T^{+} \Delta t$

Commonly, a daily time interval is used for temperature integration, although any other time interval, such as hourly or monthly can also be used for determining degree-day factors. Reported degreeday factors from glaciers and snow-covered basins including site characteristics are summarized in Table 1, elaborating on previous similar tables by e.g. Braithwaite and Zhang (2000) or Singh et al. (2000a). Results reveal a large variability from site to site. Values are derived from different integration periods ranging from a few days (e.g. 3 days; Singh and Kumar, 1996) to several years (e.g. 512 days over a 6year period; Braithwaite, 1995), limiting direct comparison. Degree-day factors are computed either from direct measurements, using snow lysimeter outflow (e.g. Kustas and Rango, 1994) or ablation stakes (e.g. Braithwaite et al., 1998), or from melt obtained by energy balance computations (e.g. Arendt and Sharp, 1999). For the same site, values might be sensitive to the way they are derived, for instance, how mean daily temperature is computed (Singh et al., 2000a) or which temporal average is used (Arnold and MacKay, 1964). Use of daily temperature mean can be misleading during times of temperature fluctuations 
are degree-day factors (DDF) on snow and bare ice in $\mathrm{mm} \mathrm{d}^{-1}{ }^{\circ} \mathrm{C}^{-1}$

\section{Glaciers}

Alps/New Zealand/America

Aletschgletscher (Switzerland)

Morenoglacier (Argentina)

John Evans Glacier (Canada)

5.5

Scandinavia/Spitzbergen/Iceland

Alfotbreen (Norway)

Hellstugubreen (Norway)

Nigardsbreen (Norway)

Storglaciären (Sweden)

$4.5^{\mathrm{a}}$

$3.5^{\mathrm{a}}$

$4.0^{\mathrm{a}}$

3.2

Vestfonna (Spitzbergen)

Satujökull (Iceland)

Dokriani Glacier

Glacier AX010

Khumbu Glacier

Rakhiot Glacier

Yala Glacier

Greenland

Thule Ramp

Camp IV-EGIG ${ }^{\mathrm{f}}$
Reference

DDF ice Latitude

Altitude (m, a.s.l.)

Period

3 Aug-19 Aug 1973

2 Aug-27 Aug 1965

Jov 1993-1 Mar 94

19 Jun-14 Jul 1996

23 May-1 Jul 1998

25 Jun-19 Jul 1996

31 May-19 Jul 1998

4 Jul-16 Jul 1996

15 Jul-19 Jul 1996

2 Jul-19 Jul 1998

1961-1990

1961-1990

1961-1990

1964-1990

5 Jul-7 Sep 1993

5 Aug-12 Aug 1993

19 Jul-27 Aug 1994

9 Jul-4 Sep 1994

26 Jun-5 Aug 1958

1987-1992

Lang, 1986

Takeuchi et al., 1996

Arendt and Sharp, 1999

Arendt and Sharp, 1999

Arendt and Sharp, 1999

Arendt and Sharp, 1999

Arendt and Sharp, 1999

Arendt and Sharp, 1999

Arendt and Sharp, 1999

Arendt and Sharp, 1999

Laumann and Reeh, 1993

Laumann and Reeh, 1993

Laumann and Reeh, 1993

Johannesson et al., 1995

Hock, 1999

Hock, 1999

Hock, 1999

Hock, 1999

Schytt, 1964

$310-410$
$800-1800$

$\sim 65^{\circ} \mathrm{N}$

4 Jun-6 Jun 1995

4 days (1997-98)

Jun-Aug $1978^{\mathrm{c}}$

Jun-Aug $1978^{\mathrm{d}}$

1 Jun-31 Aug 1978

21 May-1 Jun 1999

18 Jul-6 Aug 1986

1 Jun-31 Jul $1996^{\mathrm{e}}$

1 Jun-31 Jul 1996

Johannesson et al., 1995

Singh and Kumar, 1996

Singh et al., 2000a,b

Kayastha et al., 2000a

Kayastha et al., 2000a

Kayastha et al., 2000a

Kayastha et al., 2000b

Kayastha et al., 2000b

Kayastha, 2001

Kayastha, 2001

Jul 1954

Schytt, 1955

$76^{\circ} 25^{\prime} \mathrm{N}$

Ambach, 1988a 


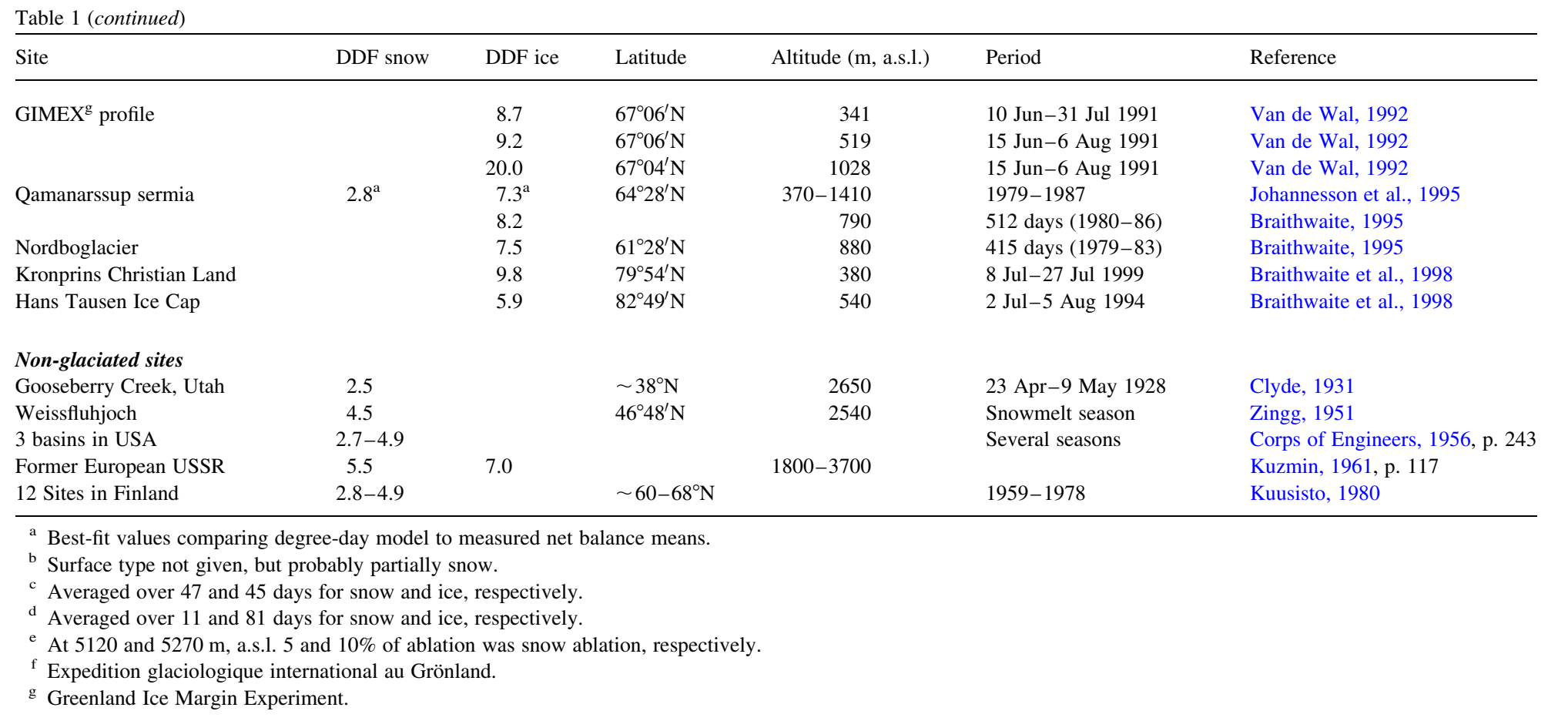


around the freezing point. Mean temperature may be negative indicating no melt, whereas melt conditions may have prevailed during part of the day. Hence, the degree-day factor will be overestimated. Consequently, a high time resolution for temperature integration is desirable.

Most of the variation in degree-day factors (Table 1) can be attributed to differences in relative importance of individual energy components providing energy for melt, since energy balance characteristics vary considerably in space and time. High shares of sensible heat flux in the heat balance are generally associated with low degree-day factors and vice versa (Ambach, 1988a,b). Ambach (1988a) attributed smaller degree-day factors at lower elevations of the Greenland ice sheet to larger ratios of sensible heat to melt energy resulting from higher values of air temperature and wind speed compared to higher elevations. Due to relatively large turbulent fluxes, including condensation, maritime environments are likely to have lower degree-day factors than more continental climate regions. For different reasons, low degree-day factors can also be expected for dry high-radiation areas where sublimation plays a major role in the heat budget. Due to high energy consumption involved, sublimation reduces considerably the energy available for melt, and thus corresponding degree-day factors (Lang and Braun, 1990). Such conditions can, e.g. be found at high elevations in the tropics and subtropics (e.g. Wagnon et al., 1999), but temporarily also in mountain areas subjected to föhn- or chinook-events (Barry, 1992). During such events, despite relatively high air temperatures, melt is subdued on the lee-side of the mountains due to low air humidity favouring sublimation, as, e.g. observed on individual days on Aletschgletscher, Switzerland (Lang et al., 1977).

Energy partitioning will vary with different climate, seasons and surfaces, resulting in a variation in degree-day factors, since these implicitly account for all terms of the heat budget. Under otherwise similar conditions, degree-day factors are expected to increase with increasing elevation, with increasing direct solar radiation input and with decreasing albedo (Fig. 1). Degree-day factors for snow tend to be considerably lower than those for ice, due to generally higher albedo of snow compared to ice. On two Greenlandic glaciers, the degree-day factor for snow

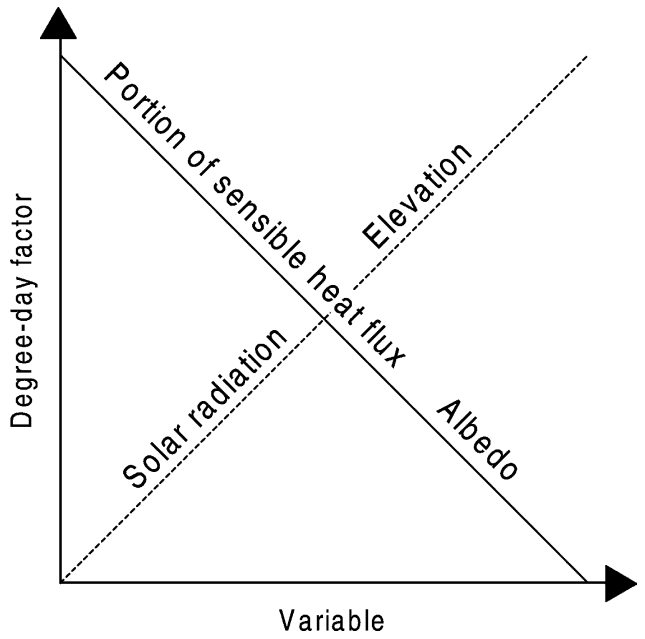

Fig. 1. Schematic plot illustrating qualitatively how degree-day factors are affected as variables increase. Degree-day factors increase as solar radiation and elevation increase and as portion of sensible heat flux and albedo decrease.

reached only about $40 \%$ of that for ice, while the corresponding percentage was about $70 \%$ on four Scandinavian glaciers. Differences were inferred to reflect a smaller albedo contrast on the Scandinavian glaciers than on the Greenland glaciers (Braithwaite, 1996). Braithwaite (1995) also found evidence for degree-day factors to depend on air temperature. Higher values tended to occur at lower temperatures, indicating a non-linearity in the melt-temperature relationship. A detailed discussion on the complex interplay between environmental factors and degreeday factors can be found in Lang and Braun (1990).

\subsection{Spatial variations}

Despite the dependency of degree-day factors on the relative importance of the sensible heat flux in the heat budget, regional patterns of degree-day factors are not detectable in the reported data (Table 1). This may be due to the complexity of the processes, including counteracting mechanisms (Fig. 1). In addition, any local signal might be subdued by variation resulting from different periods and integration times on which reported degree-day factors are based. Degree-day factors are subject to significant small-scale variability. Braithwaite et al. (1998) compared degree-day factors obtained at several 
ablation stakes spaced only a couple of metres apart and found $\mathrm{a} \pm 10 \%$ variation between stakes.

\subsection{Temporal variations}

The degree-day factor can be expected to vary seasonally due to variations in direct solar radiation and, in case of snow, due to metamorphic evolution of the snow cover causing a decrease in albedo. Degreeday factors over snow at 12 sites across Finland tended to increase sharply in the beginning of April and roughly doubled during this month due to snow ripening and associated albedo decline (Kuusisto, 1980). Over ice, seasonal variations in surface albedo, and hence in degree-day factors, tend to be less pronounced. Braithwaite and Olesen (1993) detected no evidence of distinct seasonal variation in degreeday factors, analysing six years of summer data over ice on Qamanârssûp sermia in Greenland, although monthly averages ranged from 6.2 to $9.0 \mathrm{~mm} \mathrm{~d}^{-1}{ }^{\circ} \mathrm{C}^{-1}$. Despite uncertainties in determining hourly melt rates, field studies indicate strong diurnal variations in degree-day factors. Singh and Kumar, (1996) report variations ranging from 0 to $15 \mathrm{~mm} \mathrm{~d}^{-1}{ }^{\circ} \mathrm{C}^{-1}$ roughly following diurnal cycles in shortwave incoming radiation.

\section{Models}

\subsection{Simple formulations}

In practise, the degree-day approach often assumes the form

$M= \begin{cases}f_{\mathrm{m}}\left(T_{\mathrm{d}}-T_{0}\right), & T_{\mathrm{d}}>T_{0} \\ 0, & T_{\mathrm{d}} \leq T_{0}\end{cases}$

(e.g. Gottlieb, 1980; Lang, 1986; Braun et al., 1994), where $M$ is daily melt, $T_{\mathrm{d}}$ is daily mean temperature, $T_{0}$ is a threshold temperature beyond which melt is assumed to occur, and $f_{\mathrm{m}}$ is a melt factor. It is emphasized that, when $T_{\mathrm{d}} \neq T_{0}, f_{m}$ is not the same as the degree-day factor, DDF, in Eq. (1). Therefore, I suggest to use the term melt factor instead of degreeday factor in any formulations deviating from Eq. (1) in order to avoid confusion with the original definition of a positive degree-day factor. The inclusion of a threshold temperature accounts for the fact that melt does not necessarily occur at air temperatures $>0{ }^{\circ} \mathrm{C}$ (Kuhn, 1987) as well as for potential uncertainties in air temperatures related to measurement and extrapolation errors. On the other hand, Braithwaite (1995) observed a tendency for melt to occur even when air temperatures were zero.

Many temperature-index based runoff models employ a seasonally variable melt factor. For instance, the UBC-runoff model (Quick and Pipes, 1977) adopts a monthly variable melt factor, while the HBV-ETH model determines the melt factor from sinusoidal interpolation between a minimum value on December 21 and a maximum value on June 21 (Braun et al., 1993). Schreider et al. (1997) applied the IACRESrunoff model with the degree-day factor varying according to an albedo-related factor computed for each month as a function of mean monthly temperature. A dependency of the degree-day factor on albedo was also suggested by Arendt and Sharp (1999) in order to model melt at three sites on an Arctic glacier, resulting in improved model performance compared to application of a constant degree-day factor. Modelling glacier runoff of Zongoglacier in Bolivia, Rigaudière et al. (1995) used a significantly lower degree-day factor in the dry season than in the wet season to account for the pronounced seasonality in melt rates that characterizes the glacier despite of low seasonal temperature variability typical of the tropics.

Simple degree-day formulations are also a common tool to assess the sensitivity of glacier mass balances to climate change (e.g. Laumann and Reeh, 1993; Bøggild et al., 1994; Braithwaite and Zhang, 1999; Braithwaite and Zhang, 2000). Models are generally calibrated according to measured mass balance gradients and then re-run while perturbing climate variables, mainly air temperature. Results must be interpreted with caution as the inherent assumption that degree-day factors remain constant under a different climate may not be true. However, such studies can yield valuable information about regional differences in sensitivity (e.g. Braithwaite and Zhang, 1999).

\subsection{Extended formulations}

The fact that melt factors are influenced by all components of the energy balance has prompted many 
attempts to improve the method by incorporating more variables, such as wind speed, vapour pressure or radiation components. Lang (1968) concluded from multiple regression techniques that for hourly means inclusion of global radiation and for daily means inclusion of vapour pressure improves melt water runoff computations. Also based on statistical analysis, Zuzel and Cox (1975) suggested that daily snow melt estimates could be improved by including net radiation, vapour pressure and wind speed rather than air temperature alone.

There is a gradual transition from simple degreeday approaches to energy-balance-type expressions by increasing the number of input variables into model formulations. A widely quoted method has been proposed by Anderson (1973). His so-called combination method applies a simple degree-day approach during dry periods and a simplified empirical energy balance formulation during rainy periods. The UBC-runoff-model (Quick and Pipes, 1977) and the HYMET-runoff-model (Tangborn, 1984) employ the daily temperature range in addition to air temperature as climatic input for their melt routines, as a measure of cloud-cover and, hence solar radiation. Several studies have added a radiation term to Eq. (2) in the general form

$M=f_{\mathrm{m}} T+a R$

where $a$ is a coefficient and $R$ is the shortwave radiation balance (Martinec, 1989; Kane and Gieck, 1997) or net radiation (Martinec and de Quervain, 1975; Kustas and Rango, 1994). These extended expressions have usually been tested at the site scale yielding better results compared to solely temperature based simulations. E.g. Kustas and Rango (1994) obtained an increase in $r^{2}$ by nearly $40 \%$ when moving from the basic degree-day approach to the extended expression, comparing daily model results with observations. Brubaker et al. (1996) added net radiation to the temperature-index based SRM-runoff model, but assumed net radiation uniform over the basin.

\subsection{Distributed temperature-index models}

It is well known that in mountain regions melt is heavily affected by topographic effects, such as slope, aspect and shading, yielding high spatial variability in melt rates. However, these effects are not accounted for in the basic degree-day approach, as the degreeday factor is generally assumed constant in space, although in glacier applications the factor might depend on whether the surface is ice or snow (e.g. Braun et al., 1993; Hock, 1999). In temperature-index based melt-runoff models, spatial variation of melt rates across the basin is usually considered in a crude manner. Elevation bands are often the only criterion for spatial discretisation. Hence, melt rates will only vary as a function of elevation resulting from an air temperature lapse rate. The HBV-ETH-runoff model improves upon this simplification by subdividing further into three aspect classes (Braun et al., 1994). A multiple factor, constrained by optimization procedures, is then applied for each class to account for enhanced melt on south-facing slopes and reduced melt on north-facing slopes.

Only very few studies have attempted to apply temperature-index methods in a fully distributed manner, allowing for spatially variable melt estimates on a grid (Table 2). Common to most of them is that melt rates are computed as a function of a radiation index, which heavily is affected by topographic effects, thus addressing the large variability of melt rates in mountain terrain. Dunn and Colohan (1999) divide the basin into five slope and three aspect classes $(\mathrm{N}, \mathrm{S}, \mathrm{W} / \mathrm{E})$ and vary the melt factor as a function of snow albedo, rainfall rate and monthly values of the ratio of direct solar radiation received by the sloping surface to that received by a horizontal surface. The monthly values are derived from published tables. Cazorzi and Fontana (1996) and Hock (1999) propose fully distributed temperatureindex melt models computing variable melt rates for each grid element of a digital elevation model incorporating topographic effects. Cazorzi and Fontana (1996) used monthly raster maps of clear-sky global radiation, each map obtained as average of accumulated values between 21 December and the middle of each month.

Hock (1999) proposed a model varying the melt factor for every hour and each grid cell according to the temporal and spatial variation of clear-sky direct solar radiation. The latter can be computed from standard algorithms on solar geography without the need of meteorological data using a digital elevation model. By adopting an hourly resolution, not only 
Table 2

Spatially distributed temperature-index melt models

\begin{tabular}{|c|c|c|c|c|}
\hline Melt factor is function of & $\begin{array}{l}\text { Area characteristics model is applied } \\
\text { to }\end{array}$ & Spatial discretization & Time step & Reference \\
\hline $\begin{array}{l}\text { Monthly maps of clear-sky } \\
\text { global radiation }\end{array}$ & $\begin{array}{l}\text { Upper Cordevole catchment, Italy, } \\
7 \mathrm{~km}^{2}, 1815-3150 \text { ma.s.l. }\end{array}$ & Grid-based $(20 \times 20 \mathrm{~m})$ & Hour & $\begin{array}{l}\text { Cazorzi and Fontana, } \\
1996\end{array}$ \\
\hline $\begin{array}{l}\text { Monthly values of ratio of } \\
\text { direct solar radiation received by } \\
\text { surface to that received by } \\
\text { a horizontal surface } \\
\text { Parameterized snow albedo } \\
\text { Rain fall rate }\end{array}$ & $\begin{array}{l}\text { Catchment on River Dee, Scotland } \\
293 \mathrm{~km}^{2}, 334-1309 \text { ma.s.1. }\end{array}$ & $\begin{array}{l}5 \text { slope and } 3 \text { aspect } \\
\text { classes }\end{array}$ & Day & $\begin{array}{l}\text { Dunn and Colohan, } \\
1999\end{array}$ \\
\hline Hourly potential direct solar radiation & $\begin{array}{l}\text { Storglaciären (Sweden), } 3 \mathrm{~km}^{2} \text {, } \\
1120-1730 \text { ma.s.l. }\end{array}$ & Grid-based $(30 \times 30 \mathrm{~m})$ & Hour & Hock, 1999 \\
\hline Accumulated temperature index & $\begin{array}{l}\text { Sacramento and San Joaquin basins, } \\
\text { California } 180-9500 \mathrm{~km}^{2} \text {, } \\
\text { 500-4400 ma.s.l. }\end{array}$ & Grid-based $(2 \times 2 \mathrm{~km})$ & Hour & Daly et al., 2000 \\
\hline
\end{tabular}

spatial variability in degree-day factors is considered, but also their strong diurnal variability is taken into account, since direct radiation is subject to pronounced diurnal cyclicity. Hence, the model considerably improves simulation of both, spatial distribution of melt rates and diurnal melt and discharge cycles. Fig. 2 compares runoff simulations using this model (b) to those based on the classical degree-day method (a), and a distributed energybalance model (c, Hock, 1998). While seasonal

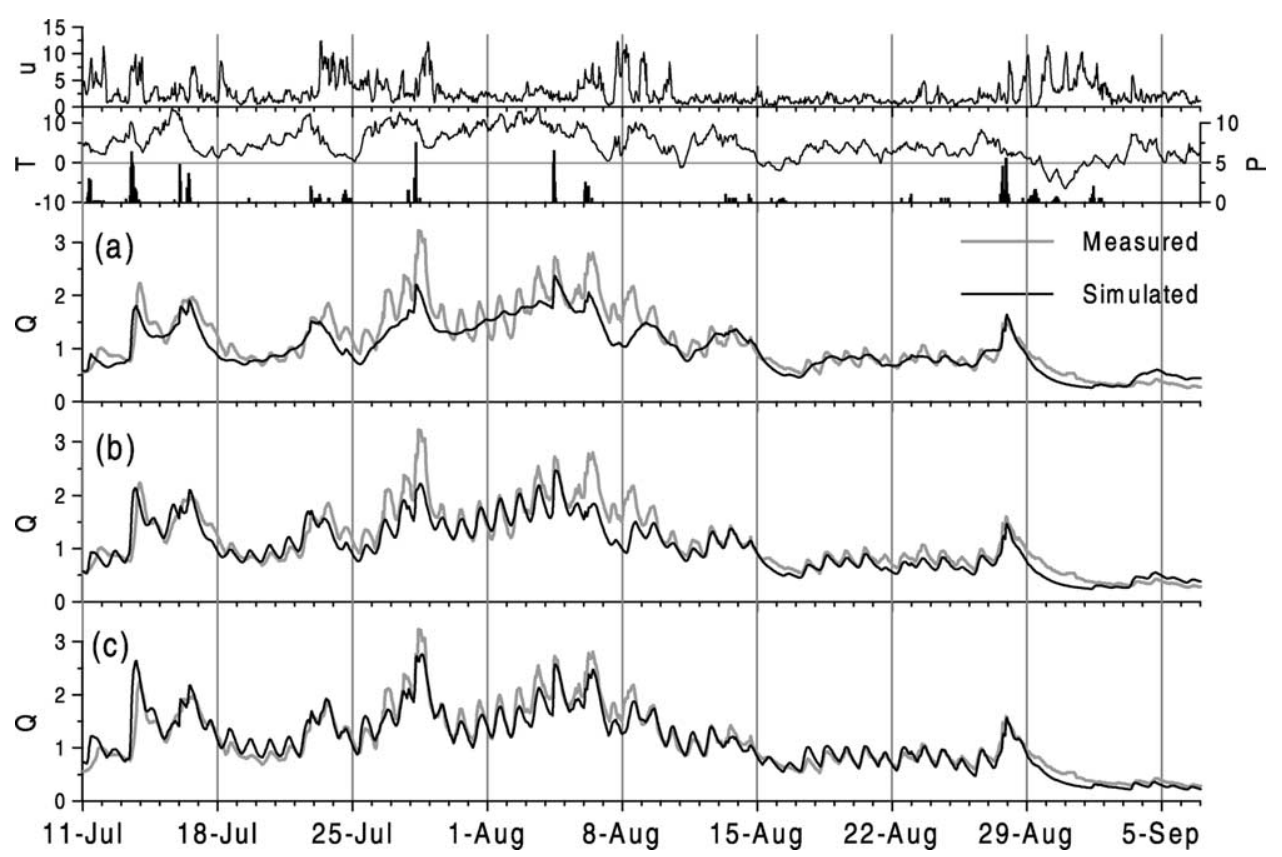

Fig. 2. Hourly data of wind speed, $u\left(\mathrm{~m} \mathrm{~s}^{-1}\right)$, air temperature, $T\left({ }^{\circ} \mathrm{C}\right)$, precipitation, $P\left(\mathrm{~mm} \mathrm{~h}^{-1}\right)$, simulated and measured hourly discharge, $Q$ $\left(\mathrm{m}^{3} \mathrm{~s}^{-1}\right)$ of Storglaciären, Sweden, from July 11 to September 6, 1994. Melt calculations are based on classical degree-day method (a), modified temperature-index model including potential direct solar radiation (b; Hock, 1999) and energy balance model (c; Hock, 1998). 
discharge variations are reasonably well modelled, it is obvious that the pronounced diurnal discharge cycles, typically for melt-affected regimes, are not properly resolved by the simple degree-day method. This aspect is considerably improved when using the modified temperature-index method, while only little additional improvement in model performance is achieved when adopting an energy balance approach.

Although strictly speaking not a temperatureindex model, but working on similar grounds as the models described above, Williams and Tarboton (1999) present a model to spatially distribute measured melt for every time step. Three components of melt are distinguished: a spatially uniform component, an elevation dependent component, and one that is proportional to solar radiation. For every time step snow melt measurements at selected index-locations are related to elevation and solar radiation by regression techniques. The resulting relationship combined with the spatial pattern of direct radiation and elevation is then used to compute spatially distributed melt over the entire catchment.

Daly et al. (2000) distribute the snow melt factor spatially according to an antecedent temperature index rather than a radiation index. The melt factor increases as a function of an accumulated temperature index up to a threshold value beyond which the melt factor remains constant.

\section{Concluding remarks}

The degree-day method has been in use in many variants for more than a century, although more physically based energy balance models more properly account for the processes determining melt. However, these are often not practical due to large data requirements and uncertainties about spatial variability of some of these data. Hence, due to generally good performance, low data requirements and simplicity, temperature-index methods are most common, and will also in the future retain their foremost position in snow and glacier melt modelling.

However, awareness of their limitations is necessary. Degree-day factors exhibit considerable spatial and temporal variability, since they depend on the relative contributions of energy balance components in the heat budget, which in turn vary with weather and surface type. Thus, the classical degreeday method is only adequate for 'average conditions', spatially defined to the catchment scale and temporarily restricted to periods exceeding a couple of days (Lang and Braun, 1990). Nevertheless, in connection with runoff models, temperature-index melt models generally yield good results even on a daily basis, as daily deviations are smoothed by the basin response (Rango and Martinec, 1995). Since there is no universal numerical value, as evident from Table 1, degree-day factors need to be adjusted to each application, and hence treated as calibration (tuning) parameters within reasonable limits in runoff- and mass balance models. Alternatively, predetermining degree-day factors based on measurements or basin characteristics (Martinec and Rango, 1986) appears problematic. Due to large small-scale variability (Hock, 1999), especially in mountain terrain, degree-day factors obtained from point measurements can generally not be assumed representative on the catchment scale. Deriving degree-day factors from physiographic basin characteristics might yield a range of reasonable values, but not a single values considering the complexity of processes and interactions between atmospheric and surface characteristics affecting the numerical value of the degree-day factor. Consequently, in degree-day driven run-off models, degree-day factors are more properly evaluated by optimization procedures using historic data to minimize discrepancies between model results and observations.

The majority of proposed modifications to the original degree-day method primarily aim at more accurately capturing seasonal variations in degree-day factors, basically adopting one of two strategies. (1) Degree-day factors are varied directly as a function of time of year, or physical surface properties, such as snow density or albedo. Most operational runoff models employ such a seasonally variable degree-day factor and additional model parameters are usually introduced to contain its variation. (2) Degree-day factors are varied indirectly by adding more input variables, often radiation components. These approaches lead to a gradual transition to simplified energy balance methods. Such attempts have mainly been tested at the point scale, often improving upon 
simpler formulations. However, they are not easily transferable from the point to the catchment scale. A daily time step is usually adopted in temperatureindex runoff modelling. However, such a time step is insufficient to accurately capture melt-induced diurnal discharge cycles or flood flows. Hence, models need to be developed that account for the diurnal variability in degree-day factors.

While temporal variability of degree-day factors has received considerable attention, it is surprising how little research has focussed on the development of spatially distributed temperature-index models specifically accounting for the large spatial variability in degree-day factors in mountain regions, in particular in steeply sided terrain. A reason might be that degree-day melt modelling has traditionally been driven by the need for operational runoff modelling with primary interest in basin runoff response and not in snow line retreat or spatially distributed melt estimates. However, in recent years an increasing need for spatially distributed estimates of melt rates has been identified (Kirnbauer et al., 1994). To cater to this demand, while retaining simple data input requirements, distributed temperature-index models need to be developed. Some recent attempts to vary degree-day factors in a fully distributed manner include potential direct solar radiation, thus exploiting the close correspondence between its spatial pattern with that of melt. Such approaches are intriguing as meteorological data input is not enhanced, while yielding more realistic spatial variations in melt estimates. These models need further testing and refinement. Nevertheless, it seems, that inclusion of potential direct solar radiation into temperature-index models can improve traditional methods with respect to spatial distribution and also diurnal variation in melt rates, without need for more data.

\section{Acknowledgements}

Comments on the manuscript by Roger Braithwaite, Andrew Fountain, Peter Jansson and Herbert Lang are gratefully acknowledged. Thanks to A. Arendt, S. Daly, R. Kayastha and R. Van de Wal for providing additional information for the tables.

\section{References}

Ambach, W., 1988a. Heat balance characteristics and ice ablation, western EGIG-profile, Greenland, Seventh Northern Research Basins Symposium/Workshop: Applied Hydrology in the Development of Northern Basins, May 25-June 1, Copenhagen Danish Society for Arctic Technology, Ililissat, Greenland, pp. 59-70.

Ambach, W., 1988b. Interpretation of the positive-degree-days factor by heat balance characteristics-West Greenland. Nord. Hydrol. 19, 217-224.

Anderson, E.A., 1973. National weather service river forecast system/snow accumulation and ablation model, NOAA Technical Memorandum NWS HYDRO-17, US Department of Commerce, Silver Spring, MD, 217 pp.

Arendt, A., Sharp, M., 1999. Energy balance measurements on a Canadian high arctic glacier and their implications for mass balance modelling. In: Tranter, M., et al. (Eds.), Interactions Between the Cryosphere, Climate and Greenhouse Gases, Proceedings of the IUGG Symposium, Birmingham 1999: IAHS Publ. no. 256, pp. 165-172.

Arnold, K.C., MacKay, D.K., 1964. Different methods of calculating mean daily temperatures, their effects on degree-day totals in the high Arctic and their significance to glaciology. Geogr. Bull. 21, 123-129.

Barry, R.G., 1992. Mountain weather and climate, second ed., Routledge Physical Environment Series, London, 402 pp.

Bergström, S., 1976. Development and application of a conceptual runoff model for Scandinavian catchments. (Department of Water Resources Engineering, Lund Institute of Technology/University of Lund, Bulletin Series A, No. 52, 134 pp.).

Bøggild, C.E., Reeh, N., Oerter, H., 1994. Modelling ablation and mass-balance sensitivity to climate change of Storstrømmen, northeast Greenland. Glob. Planet. Change 9, 79-90.

Bøggild, C.E., Knudby, C.J., Knudsen, M.B., Starzer, W., 1999. Snowmelt and runoff modelling of an arctic hydrological basin in east Greenland. Hydrol. Proc. 13, 1989-2002.

Braithwaite, R.J., 1995. Positive degree-day factors for ablation on the Greenland ice sheet studied by energy-balance modelling. J. Glaciol. 41 (137), 153-160.

Braithwaite, R.J., 1996. Models of ice-atmosphere interactions for the Greenland ice sheet. Ann. Glaciol. 23, 149-153.

Braithwaite, R.J., Olesen, O.B., 1989. Calculation of glacier ablation from air temperature, West Greenland. In: Oerlemans, J., (Ed.), Glacier Fluctuations and Climatic Change, Glaciology and Quaternary Geology, Dordrecht, pp. 219-233.

Braithwaite, R.J., Olesen, O.B., 1990. Response of the energy balance on the margin of the Greenland ice sheet to temperature changes. J. Glaciol. 36 (123), 217-221.

Braithwaite, R.J., Olesen, O.B., 1993. Seasonal variation of ice ablation at the margin of the Greenland ice sheet and its sensitivity to climate change, Qamanârssûp sermia, West Greenland. J. Glaciol. 39 (132), 267-274.

Braithwaite, R.J., Zhang, Y., 1999. Modelling changes in glacier mass balance that may occur as a result of climate changes. Geogr. Ann. 81A (4), 489-496. 
Braithwaite, R.J., Zhang, Y., 2000. Sensitivity of mass balance of five Swiss glaciers to temperature changes assessed by tuning a degree-day model. J. Glaciol. 46 (152), 7-14.

Braithwaite, R.J., Konzelmann, T., Marty, C., Olesen, O.B., 1998. Errors in daily ablation measurements in northern Greenland, 1993-94, and their implications for glacier climate studies. J. Glaciol. 44 (148), 583-588.

Braun, L.N., Grabs, W., Rana, B., 1993. Application of a conceptual precipitation-runoff model in the Langtang Khola basin, Nepal Himalaya. In: Young, G.J., (Ed.), Snow and Glacier Hydrology, Proceedings of the Kathmandu Symposium 1992: IAHS Publ. no. 218, pp. 221-237.

Braun, L.N., Aellen, M., Funk, M., Hock, R., Rohrer, M.B., Steinegger, U., Kappenberger, G., Müller-Lemans, H., 1994. Measurement and simulation of high alpine water balance components in the Linth-Limmern head watershed (Northeastern Switzerland). Z. Gletscherkd. Glazialgeol. 30, 161-185.

Brubaker, K., Rango, A., Kustas, W., 1996. Incorporating radiation inputs into the snowmelt runoff model. Hydrol. Proc. 10, 1329-1343.

Cazorzi, F., Fontana, G.D., 1996. Snowmelt modelling by combining air temperature and a distributed radiation index. J. Hydrol. 181, 169-187.

Clyde, G.D., 1931. Snow-melting characteristics. Utah Agricultural Experiment Station Bull. 231, 1-23.

Collins, E.H., 1934. Relationship of degree-days above freezing to runoff. Trans. Am. Geophys. Union, Reports and Papers, Hydrol., 624-629.

Corps of Engineers, 1956. Summary report of the snow investigations, snow hydrology. US Army Engineer Division (North Pacific, 210 Custom House, Portland, Oregon), 437 pp

Daly, S.F., Davis, R., Ochs, E., Pangburn, T., 2000. An approach to spatially distributed snow modelling of the Sacramento and San Joaquin basins, California Hydrol. Proc. 14, 3257-3271.

Dunn, S.M., Colohan, R.J.E., 1999. Developing the snow component of a distributed hydrological model: a step-wise approach based on multi-objective analysis. J. Hydrol. 223, 1-16.

Finsterwalder, S., Schunk, H., 1887. Der Suldenferner. Zeitschrift des Deutschen und Oesterreichischen Alpenvereins 18, 72-89.

Gottlieb,L., 1980. Development and applications of a runoff model for snowcovered and glacierized basins. Nord. Hydrol. 11, 255-284.

Hock, R., 1998. Modelling of glacier melt and discharge. Zürcher Geographische Schriften 70, Geogr. Inst. ETH Zürich, ISBN 3906148-18-1, 140 pp

Hock, R., 1999. A distributed temperature-index ice- and snowmelt model including potential direct solar radiation. J. Glaciol. 45 (149), 101-111.

Hoinkes, H.C., Steinacker, H., 1975. Hydrometeorological implications of the mass balance of Hintereisferner, 1952-53 to 1968-69, Proceedings of the snow and ice symposium, Moscow 1971. IAHS Publ. no. 104, pp. 144-149.

Jansson, P., Hock, R., Schneider, T., 2003. The concept of glacier storage-a review. J. Hydrol..

Johannesson, T., Sigurdsson, O., Laumann, T., Kennett, M., 1995. Degree-day glacier mass-balance modelling with applications to glaciers in Iceland, Norway and Greenland. J. Glaciol. 41 (138), $345-358$.
Kane, D.L., Gieck, R.E., 1997. Snowmelt modeling at small Alaskan arctic watershed. J. Hydrol. Engng. 2 (4), 204-210.

Kayastha, R.B., 2001. Study of glacier ablation in the Nepalese Himalayas by the energy balance model and positive degree-day method. PhD Thesis. Graduate School of Science, Nagoya University, $95 \mathrm{pp}$

Kayastha, R.B., Ageta, Y., Nakawo, M., 2000a. Positive degree-day factors for ablation on glaciers in the Nepalese Himalayas: case study on glacier AX010 in Shoron Himal, Nepal. Bull. Glaciol. Res. 17, 1-10.

Kayastha, R.B., Takeuchi, Y., Nakawo, M., Ageta, Y., 2000b. Practical prediction of ice melting beneath various thickness of debris cover on Khumbu Glacier, Nepal, using a positive degreeday factor. In: Nakawo, M., Raymond, C.F., Fountain, A. (Eds.), Debris-Covered Glaciers, IAHS Publ. no. 264, pp. 71-81.

Kirnbauer, R., Blöschl, G., Gutknecht, D., 1994. Entering the era of distributed snow models. Nord. Hydrol. 25 (1/2), 1-24.

Kuhn, M., 1987. Micro-meteorological conditions for snow melt. J. Glaciol. 33 (113), 263-272.

Kuhn, M., 1993. Methods of assessing the effects of climatic changes on snow and glacier hydrology. In: Young, G.J., (Ed.), Snow and glacier hydrology. Proceedings of the Kathmandu Symposium 1992: IAHS Publ. no. 218, pp. 135-144.

Kustas, W.P., Rango, A., 1994. A simple energy budget algorithm for the snowmelt runoff model. Water Resour. Res. 30 (5), $1515-1527$

Kuusisto, E., 1980. On the values and variability of degree-day melting factors in Finland. Nord. Hydrol. 11 (5), 235-242.

Kuzmin, P.P., 1961. Melting of snow cover, Israel Program for Scientific Translation, $290 \mathrm{pp}$.

Lang, H., 1968. Relations between glacier runoff and meteorological factors observed on and outside the glacier, IUGG General Assembly, Berne, International Association of Scientific Hydrology: IAHS Publ. no. 79, pp. 429-439.

Lang, H., 1986. Forecasting meltwater runoff from snow-covered areas and from glacier basins. In: Kraijenhoff, D.A., Moll, J.R. (Eds.), River Flow Modelling and Forecasting, D. Reidel publishing company, pp. 99-127, Chapter 5.

Lang, H., Braun, L., 1990. On the information content of air temperature in the context of snow melt estimation. In: Molnar, L., (Ed.), Hydrology of Mountainous Areas, Proceedings of the Strbske Pleso Symposium 1990: IAHS Publ. no. 190, pp. $347-354$.

Lang, H., Schädler, B., Davidson, G., 1977. Hydrological investigations on the Ewigschneefeld-Gr. Aletschgletscher. Z. Gletscherkd. Glazialgeol. 12 (2), 109-124.

Laumann, T., Reeh, N., 1993. Sensitivity to climate change of the mass balance of glaciers in southern Norway. J. Glaciol. 39 (133), 656-665.

Martinec, J., 1989. Hour-to-hour snowmelt rates and lysimeter outflow during an entire ablation period. In: Colbeck, S.C., (Ed.), Glacier and Snow Cover Variations, Proceedings of the Baltimore Symposium, Maryland 1989: IAHS Publ. no. 183, pp. 19-28.

Martinec, J., de Quervain, M.R., 1975. The effect of snow displacement by avalanches on snow melt and runoff, Snow 
and Ice Symposium. Proceedings of Moscow Symposia, 1971: IAHS Publ. no. 104, pp. 365-377.

Martinec, J., Rango, A., 1986. Parameter values for snowmelt runoff modelling. J. Hydrol. 84, 197-219.

Oerlemans, J., Anderson, B., Hubbard, A., Huybrechts, P., Johannesson, T., Knap, W.H., Schmeits, M., 1998. Modelling the response of glaciers to climate warming. Clim. Dyn. 14, 267-274.

Ohmura, A., 2001. Physical basis for the temperature-based meltindex method. J. Appl. Meteorol. 40, 753-761.

Quick, M.C., Pipes, A., 1977. UBC watershed model. Hydrol. Sci. Bull. 221, 153-161.

Rango, A., Martinec, J., 1995. Revisiting the degree-day method for snowmelt computations. Water Resour. Bull. 31 (4), 657-669.

Rigaudière, P., Ribstein, P., Francou, B., Pouyaud, B., Saravia, R., 1995. Un modèle hydrologique du glacier du Zongo, Rapport No. 44, ORSTOM, Bolivie. 90pp.

Röthlisberger, H., Lang, H., 1987. Glacial hydrology. In: Gurnell, A.M., Clark, M.J. (Eds.), Glacio-fluvial Sediment Transfer, An Alpine Perspective, Wiley, New York, pp. 207-284, Chapter 10.

Sato, A., Takahashi, S., Naruse, R., Wakahama, G., 1984. Ablation and heat balance of the Yukikabe snow patch in the Daisetsu mountains. Ann. Glaciol. 5, 122-126.

Schreider, S.Y., Whetton, P.H., Jakeman, A.J., Pittock, A.B., 1997. Runoff modelling for snow-affected catchments in the Australian alpine region, eastern Victoria. J. Hydrol. 200, 1-23.

Schytt, V., 1955. Glaciological investigations in the Thule Ramp area. SIPRE Report 28, Snow, ice and permafrost research establishment, Corps of Engineers, US Army, Wilmette, Illinois. $88 \mathrm{pp}$

Schytt, V., 1964. Scientific results of the Swedish glaciological expedition to Nordaustlandet, Spitzbergen, 1957 and 1958. Geogr. Ann. 46 (3), 243-281.
Singh, P., Kumar, N., 1996. Determination of snowmelt factor in the Himalayan region. Hydrol. Sci. J. 41 (3), 301-310.

Singh, P., Kumar, N., Arora, M., 2000a. Degree-day factors for snow and ice for Dokriani Glacier, Garhwal Himalayas. J. Hydrol. 235, 1-11.

Singh, P., Kumar, N., Ramasastri, K.S., Singh, Y., 2000b. Influence of a fine debris layer on the melting of snow and ice on a Himalayan glacier. In: Nakawo, M., Raymond, C.F., Fountain, A. (Eds.), Debris-covered Glaciers, Proceedings of the Workshop on Debris-covered Glaciers, Seattle, 2000: IAHS Publ. no. 264, pp. 63-69.

Takeuchi, Y., Naruse, R., Skvarca, P., 1996. Annual air-temperature measurement and ablation estimate at Moreno Glacier, Patagonia. Bull. Glacier Res. 14, 23-28.

Tangborn, W.V., 1984. Prediction of glacier derived runoff for hydro-electric development. Geogr. Ann. 66A (3), 257-265.

Van de Wal, R., 1992. Ice and climate. PhD Thesis, Utrecht University, $144 \mathrm{pp}$

Wagnon, P., Ribstein, P., Kaser, G., Berton, P., 1999. Energy balance and runoff seasonality of a Bolivian glacier. Glob. Planet. Change 22, 49-58.

Williams, K.S., Tarboton, D.G., 1999. The ABC's of snowmelt: a topographically factorized energy component snowmelt model. Hydrol. Proc. 13 (12-13), 1905-1920.

WMO, 1986. Intercomparison of models for snowmelt runoff. Operational Hydrology Report 23 (WMO No. 646).

Zingg, T., 1951. Beziehung zwischen Temperatur und Schmelzwasser und ihre Bedeutung für Niederschlags-und Abflussfragen. IAHS Publ. no. 32, 266-269.

Zuzel, J.F., Cox, L.M., 1975. Relative importance of meteorological variables in snowmelt. Water Resour. Res. 11 (1), $174-176$. 